\title{
Culture of the Nile tilapia (Oreochromis niloticus) in a recirculating water system using different protein levels
}

\author{
Mohamed H. Bahnasawy ${ }^{1}$, Ahmed E. El-Ghobashy ${ }^{1}$ and Nabil F. \\ Abdel-Hakim ${ }^{2}$ \\ 1- Zoology department, Damietta Faculty of Sci., Mansoura Univ. \\ 2- Faculty of Agriculture, Al-Azhar University, Egypt.
}

\begin{abstract}
The study investigated the effect of dietary protein levels on growth 1 performance and body composition of the Nile tilapia, Oreochromis niloticus fingerlings ( $8.0 \mathrm{~g})$, using a recirculating water system. The system consisted of eight rearing concrete tanks, underground plastic tank acts as a clarifier and upper plastic tank acts as a biofilter. The system was supplied with air and water pumps. Fish were fed on four dietary protein levels $(20 \%, 25 \%$, $30 \%$ and 35\%) to satiaty for 6 days a week for 6 months. Results showed that fish growth was significantly affected by protein level. Fish fed on $30 \%$ protein diet attained the highest growth (higher weight gain, higher daily weight gain and higher specific growth rate). The best food conversion ratio (FCR) (2.05) was obtained by $30 \%$ protein diet, while the poorest FCR (2.72) was obtained by $20 \%$ protein diet. Protein efficiency ratio (PER) was significantly affected by protein levels. It decreased with increasing protein level. Results of body composition showed that protein and lipid contents were significantly affected by protein level. Protein content was significantly increased with increasing protein level in the diet. In contrast, lipid content was inversely affected by increasing the dietary protein level. The study showed that the recirculating water system is suitable for Nile tilapia culture in Egypt, and that a diet containing $30 \%$ crude protein is economical and suitable for Nile tilapia fingerlings feeding.
\end{abstract}

Key words: aquaculture, recirculating water system, Nile tilapia, protein level, growth performance, body composition.

\section{INTRODUCTION}

Aquaculture is a growth industry striving to satisfy a growing market for food fish. It is currently one of the fastest growing sectors of agriculture in Egypt. Growing public demand for healthy tasty and affordable food is stimulating the "boom" in this industry. The decline in wild fish population as a result of over harvest and water pollution has promoted the culture of farm-fish that are grown in contaminant-free waters in indoor tank system.

Recirculation aquaculture system (RAS) represents a new and unique way to farm fish. Instead of the traditional method of growing fish outdoors in 
open ponds and raceways, this system rears fish at high densities, in indoors tanks with a controlled environment. Recirculating system filter and clean the water for recycling back through fish culture tanks ( Helfrich and Libey, 2006).

RAS offers fish producers a variety of important advantages over open pond culture. These include a method to maximize production on a limited supply of water and land, nearly complete environmental control to maximize fish growth year-around, the flexibility to locate production facilities near large markets, complete and convenient harvesting, and quick and effective disease control.

Because RAS recycle most of their water, they consume considerable less than other types of culture and are especially well adapted to areas with limited water supplies. The required quantity of water needed to grow fish varies with the species of fish farmed, size of the culture system, and investment size (Losordo et al.,1998). Since water is reused, the water volume requirements in RAS are only about $20 \%$ of what conventional open pond culture demands. They offer a promising solution to water use conflicts, water quality, and waste disposal. These concerns will continue to intensify in the future as water demand for a variety of uses escalates.

RAS are particularly useful in areas where land and water are expensive and not readily available. They require relatively small amounts of land and water. They can be located close to large markets (urban areas) and thereby reduce hauling distances and transportation costs. RAS can use municipal water supplies (after decholorination) and discharge waste into sanitary sewer system (Brazil, 2006).

Combining the farming of fish and green house vegetables has grown increasingly in popularity and profitability. Double cropping of both fish and vegetables is a new way to integrate two forms of agriculture into a single enterprise. A major advantage of rearing two high value crops such as fish and tomatoes is that waste water from the fish tank is used to irrigate and fertilize the plants. At the same time, tomato beds are used as sand bio-filters to clean the water of ammonia wastes so that it can be recycled back into the fish tanks, The horticulture-aquaculture enterprise recycles waste products and doubles the crops and profits.

RAS are more suitable for warm water fish such as channel catfish, stripped bass and tilapia that can tolerate lower water quality conditions and higher temperature (Helfrich and Libey, 2006). Tilapia is one of the most important fish farmed worldwide and is considered the most intensive cultivated freshwater fish in Egypt as well (Abdel-Hakim et al.,2001; El-Sayed,2002).

Tilapia are sometimes known as "aquatic chicken" due to their high growth rates, adaptability to a wide range of environmental conditions, and ability to grow and reproduce in captivity and feed on low trophic levels. As a result, these fishes have become excellent candidates for aquaculture, especially in tropical and subtropical regions. Indeed, tilapia culture has been expanding 
rapidly, and is now practiced in more than one hundred countries world wide (Sayed, 2006).

Nutrition and feeding play a central role in sustainable aquaculture and therefore, feed resources as well as costs continue to dominate aquaculture needs. Feed accounts for $40-60 \%$ of the production costs in aquaculture, with protein sources accounting for a significant proportion of this cost (Fotedar, 2004). It is important to minimize the amount of protein used for energy, because protein is usually the most expensive major constituents in a diet. The energy need of the fish can be met by less expensive lipid and carbohydrate. So, the amount of protein in the diet should be just enough for fish growth, where the excess protein in fish diet may be wasteful and cause diets to be unnecessary expensive (Ahmad, 2000). Realization of the optimum protein level for cultured fish would help to reduce the costs and maximize the feed conversion efficiency (Charles et al., 1984; Sampath, 1984; Chiu et al., 1987). Therefore, the objective of this study was to assess the optimum protein level leading to optimum growth of the Nile tilapia, Oreochromis niloticus, using a recirculating water system.

\section{MATERIALS AND METHODS}

Recirculating water system (Fig.1) was used for conducting the experiment of this study. The system consists of eight rearing concrete tanks, clarifier (settling tank) to remove solid wastes (feces and uneaten feed) and another two upper plastic tanks used as biofilter to remove toxic waste products (ammonia and nitrites) that are produced by the fish. Each rearing tank was 2.9 $\mathrm{m}$ long, $1.4 \mathrm{~m}$ wide and $1 \mathrm{~m}$ deep. Chlorine-free tap water is used in operating the systemthe

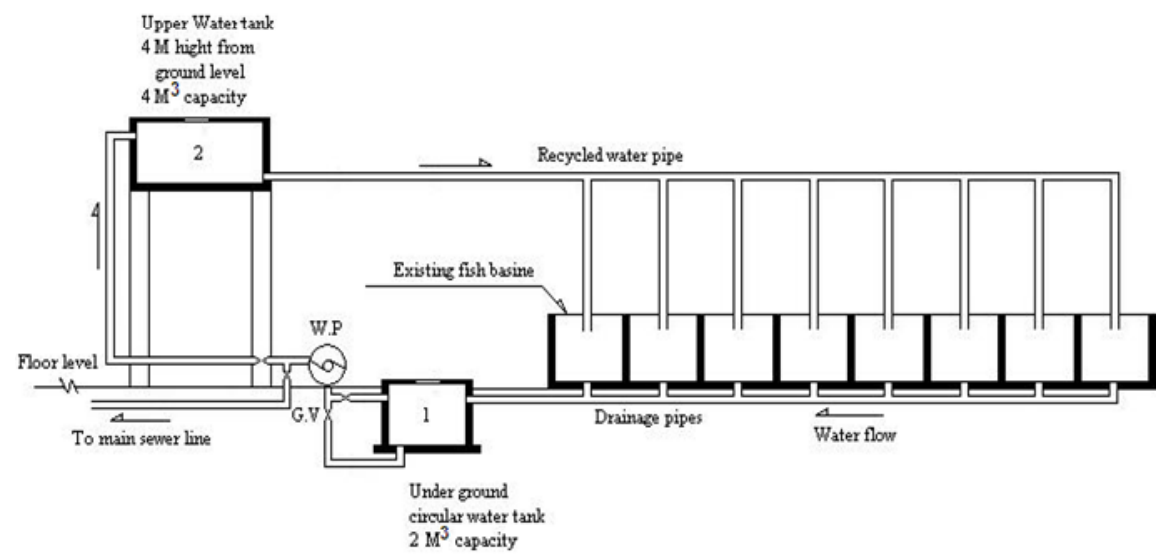

Fig.1: The recirculating water system used in the present study. 
The level of water was kept at $80 \mathrm{~cm}$ deep to maintain the water volume at $3.2 \mathrm{~m}^{3}$. Smooth surfaces were set on the inside of the tanks to prevent skin abrasions and infections to the fish and to permit cleaning and sterilization. Fingerlings of monosex Nile tilapia with an average weight of $8.0 \mathrm{~g}$ were used in this experiment. The fish were obtained from private fish hatchery at Damietta governorate. The fish were transported in oxygenated plastic bags and acclimatized for one week before stocking in the rearing tanks, where they were fed a commercial diet containing $25 \%$ crude protein. The stocking density was $198 \mathrm{fish} / \operatorname{tank}\left(60 \mathrm{fish} / \mathrm{m}^{3}\right.$ ). The fish were divided into duplicated four groups to feed by four experimental diets (Table 1) containing 20\%, 25\%, 30\% and 35\% crude protein. The fish were fed to satiaty once a day for 6 days a week for six months (from the first of May to the end of October, 2005). The amount of consumed feed for each tank was subsequently calculated.

Table (1): Composition and proximate analysis of the tested diets on dry weight basis.

\begin{tabular}{|c|c|c|c|c|}
\hline \multirow{2}{*}{ Parameters } & \multicolumn{4}{|c|}{ Dietary protein } \\
\cline { 2 - 5 } & $20 \%$ & $25 \%$ & $30 \%$ & $35 \%$ \\
\hline Soybean & 15,0 & 20,0 & 41,5 & 36,0 \\
Yellow corn & 38,0 & 52,0 & 20,0 & 28,0 \\
Wheat bran & 34,0 & - & 21,0 & - \\
Fish meal & - & 14,0 & - & 21,0 \\
Concentrates & 6,5 & - & 10,5 & - \\
Corn gluten meal & 2,0 & - & 2,0 & - \\
Clover meal & - & 10,0 & - & 10,0 \\
Oil & 1,0 & - & 0,25 & - \\
Vitamins & 1,0 & 2,0 & 1,0 & 2,0 \\
Minerals & 1,5 & 1,0 & 2,0 & 2,0 \\
Vitamin C & 1,0 & 1,0 & 1,75 & 1,0 \\
\hline Total & 100,00 & 100,00 & 100,00 & 100,00 \\
& & & & \\
Proximate analysis (\% of dry & & & & \\
matter) & & & 3,0 & 35,04 \\
Crude protein & 20,0 & 25,01 & 30,06 & 3,50 \\
Ether extracts & 3,41 & 3,55 & 2,75 & 5,89 \\
Ash & 3,24 & 4,38 & 4,02 & 5,79 \\
Crude fiber & 5,60 & 5,75 & 5,92 & \\
NFE* & 67,75 & 4328 & 4327 & \\
GE**(Kcal/100g) & 4312 & & & \\
\hline
\end{tabular}

*Nitrogen-Free extract, calculated by difference.

**Gross energy, calculated on the basis of 5.65, 4.1 and 9.5 Kcal GE/g protein, NFE and lipid, respectively. 
All the tanks were aerated by a complete system of air pumps during the whole period of the experiment. Besides air pumps, blowers were used to supply excess oxygen. To follow up the fish growth, fish samples (10-15 fish) from each tank were weighed monthly (Fig. 2). Water quality parameters (Table 2) were measured every two weeks according to APHA (1992). At the end of the experimental period, the fish of each tank were counted and weighed. Representative fish (10-15 fish) from each tank were taken and frozen for subsequent proximate analyses of carcass composition (body water, protein, lipid and Ash) according to AOAC (1990).

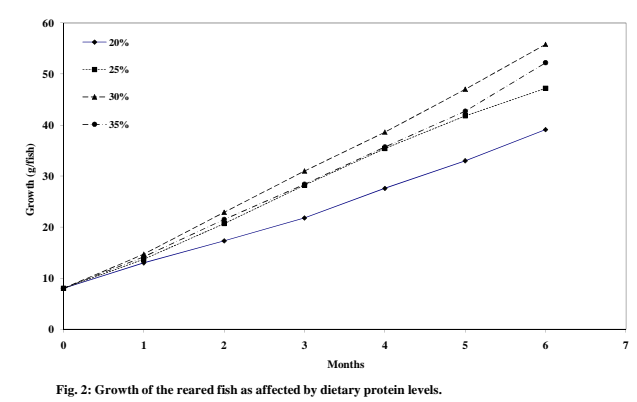

Growth performance of the experimental fish were calculated as follows:

Weight Gain (WG) = final weight (g)- initial weight (g).

Average Daily weight gain (ADG) = weight gain (g)/ time (days)

Food conversion Ratio (FCR) = diet fed (g)/ total weight gain (g)

Specific Growth Rate (SGR) = 100[ Ln final weight (g) - Ln initial weight (g)]/ Time (days)

Protein Efficiency Ratio (PER)=wet weight gain (g)/Amount of protein given (g) Incidence Cost (IC) = cost of consumed feed / Fish produced (g)

Profit Index (PI) = Value of fish crop / Cost of consumed feed

Data were subjected to analysis of variance (ANOVA) to determine the effect of dietary protein levels on growth performance of the fish. If ANOVA indicated significant treatment effects, the least significant difference (LSD) test was used to determine differences among individuals treatment means (Snedecor and Cochran, 1989). Differences were considered significant at $\mathrm{P}<0.05$. 


\section{RESULTS A ND DISCUSSION}

The mean values of water quality parameters measured in the rearing tanks are summarized in table 2. The average water temperature was $27.5{ }^{\circ} \mathrm{C}$ (23.5-31.5 ${ }^{\circ} \mathrm{C}$ ). This temperature has been reported as the optimum range for tilapia growth and yield (Meske, 1985). The average dissolved oxygen was 6.9 ppm (5.6-8.2 ppm). Siddiqui et al.(1989) stated that tilapia has a low oxygen demand and can survive at low oxygen levels. Riche and Garling (2003) reported that dissolved oxygen levels should be maintained above $5.0 \mathrm{ppm}$ for best growth.

Table (2): Water quality parameters in the rearing tanks during the experiment.

\begin{tabular}{|l|c|c|c|}
\hline Parameters & Average & Minimum & Maximum \\
\hline Water temperature $\left({ }^{\circ} \mathrm{C}\right)$ & 27,5 & 23,5 & 31,5 \\
Dissolved oxygen $(\mathrm{mg} / \mathrm{L})$ & 6,9 & 5,6 & 8,2 \\
$\mathrm{pH}$ & 7,8 & 7,2 & 8,4 \\
Ammonia (mg/L) & 0,11 & 0,06 & 0,43 \\
Nitrite (mg/L) & 0,43 & 0,08 & 1,03 \\
Nitrate (mg/L) & 0,58 & 0,23 & 1,07 \\
\hline
\end{tabular}

The $\mathrm{pH}$ of water affects many water quality parameters and the rates of many biological and chemical processes. Thus, $\mathrm{pH}$ is considered an important parameters to be monitored and controlled in recirculating aquaculture system (Losordo et al., 1998). In the present study, the average value of $\mathrm{pH}$ was 7.8 (7.2-8.4). Pompa and Masser (1999) reported that tilapia can survive at $\mathrm{pH}$ ranging from 5 to 10 but they do best at a $\mathrm{pH}$ range from 6 to 9 .

Ammonia and Nitrite are a concern in intensive recirculating systems and should be monitored regularly. Ammonia production is directly related to feeding and depends on the quality of feed, feeding rate, fish size and temperature (Riche and Garling, 2003). In the present study, ammonia, nitrites and nitrate concentrations in the rearing tanks were within the safe range for tilapia culture (Losordo et al.1998).

Growth performance parameters for tilapia fingerlings after the feeding trial are presented in Table 3. It is evident that there is a significant effects of dietary protein on growth performance of the experimental fish. WG, ADG and SGR increased significantly with increasing dietary protein levels from $20 \%$ to $30 \%$ and slightly decreased insignificantly thereafter, i.e. for diet with $35 \%$ crude protein. However the difference between the growth values obtained by $30 \%$ and $35 \%$ protein diet is not significant. Fish fed on 30\% protein diet thus exhibited the highest growth (higher weight gain, higher average daily gain, higher specific growth rate and lower feed conversion rate). Similar findings 
have been reported by different authors for different tilapia species (Wang et al. 1985; Siddiqui et al., 1988; Omar, 1994 b; Abdelghany, 2000; Abdel-Hakim et al.,2001; Coyle et al.,2004).

Table (3): Growth parameters of tilapia fed practical diets with different protein levels.

\begin{tabular}{|c|c|c|c|c|c|c|c|c|c|c|c|c|c|c|}
\hline \multirow{3}{*}{$\begin{array}{c}\text { Parameters } \\
\text { Weight gain (WG) }\end{array}$} & \multicolumn{12}{|c|}{ Protein level } & \multicolumn{2}{|c|}{ Anova } \\
\hline & \multicolumn{3}{|c|}{$20 \%$} & \multicolumn{3}{|c|}{$25 \%$} & \multicolumn{3}{|c|}{$30 \%$} & \multicolumn{3}{|c|}{$35 \%$} & \multirow{2}{*}{$\begin{array}{r}\text { F value } \\
31,44\end{array}$} & \multirow{2}{*}{$\begin{array}{l}\text { Sig. } \\
0,0\end{array}$} \\
\hline & 31,07 & \pm & $3.55^{\mathrm{a}}$ & 39,20 & \pm & $0.3^{\mathrm{b}}$ & 47,80 & \pm & $0.6^{c}$ & 44,27 & \pm & $2.66^{\mathrm{c}}$ & & \\
\hline Average daily gain (ADG) & 0,17 & \pm & $0.02^{\mathrm{a}}$ & 0,22 & \pm & $0.0^{\mathrm{b}}$ & 0,27 & \pm & $0.01^{\mathrm{c}}$ & 0,24 & \pm & $0.02^{\mathrm{bc}}$ & 30,73 & 0,0 \\
\hline Specific growth rate (SGR) & 0,88 & \pm & $0.05^{\mathrm{a}}$ & 0,99 & \pm & $0.01^{\mathrm{b}}$ & 1,08 & \pm & $0.01^{\mathrm{c}}$ & 1,04 & \pm & $0.03^{\mathrm{bc}}$ & 25,51 & 0,0 \\
\hline Feed conversion ratio (FCR) & 2,72 & \pm & $0.21^{\mathrm{a}}$ & 2,43 & \pm & $0.02^{\mathrm{b}}$ & 2,05 & \pm & $0.01^{\mathrm{c}}$ & 2,14 & \pm & $0.07^{\mathrm{c}}$ & 22,53 & 0,0 \\
\hline Protein efficiency ratio (PER) & 1,85 & \pm & $0.14^{\mathrm{a}}$ & 1,65 & \pm & $0.02^{\mathrm{b}}$ & 1,63 & \pm & $0.01^{\mathrm{b}}$ & 1,34 & \pm & $0.04^{c}$ & 24,63 & 0,0 \\
\hline Survival rate (SR) & 93,50 & \pm & $6.6^{\mathrm{a}}$ & 54,30 & \pm & $4.3^{\mathrm{b}}$ & 90,40 & \pm & $1.0^{\mathrm{a}}$ & 72,00 & \pm & $14.4^{\mathrm{c}}$ & 14,68 & 0,001 \\
\hline Incidence cost (IC) & 3,23 & \pm & $0.17^{\mathrm{a}}$ & 2,83 & \pm & $0.03^{\mathrm{bc}}$ & 2,80 & \pm & $0.01^{\mathrm{c}}$ & 3,02 & \pm & $0.12^{\mathrm{bd}}$ & 10,98 & .0 .003 \\
\hline Profit Index (PI) & 1,56 & \pm & $0.09^{\mathrm{a}}$ & 1,77 & \pm & $0.02^{\mathrm{b}}$ & 1,97 & \pm & $0.01^{\mathrm{c}}$ & 1,63 & \pm & $0.04^{\mathrm{a}}$ & 44,92 & 0,0 \\
\hline
\end{tabular}

Values with different superscripts within each row are significantly different at $\mathrm{p}<0.05$

Many authors obtained conflicting results from their studies on the effect of dietary protein levels on the growth of Nile tilapia. Based on various studies, Balarin and Halfer (1982) made a general conclusion that fry of tilapia < $1 \mathrm{~g}$ requires diet with $35-50 \%$ protein, $1-5 \mathrm{~g}$ fish requires diet with $30 \%-40 \%$ protein and $5-25 \mathrm{~g}$ fish requires diet with $25 \%-35 \%$ protein. Wee and Tuan (1988) found that the minimum dietary protein requirements for non-spawning and spawning O.niloticus was $27.5 \%$ and $35 \%$ crude protein respectively. Similarly, De Silva et al. (1989) demonstrated that the most economical dietary protein requirement for young tilapia (1 to $5 \mathrm{~g}$ ) was $28 \%$, however, maximum growth was achieved at about $34 \%$. EL-Sayed and Teshima (1991) stated that the dietary protein requirement of several species of tilapia had been estimated to range between $20 \%$ and $56 \%$. Nile tilapia reared in cages exhibited their highest growth on diet containing 32\% CP (Kheir, 1997) and 28-32\% CP (Abdel-Hakim and Moustafa, 2000). The optimum dietary protein levels for growth of Nile tilapia different strains were found to be $27 \%$ for Aswan strain, 37\% for Abassa strain and 32\% for Manzalah and Maryut strain (Khattab et al.,2000). In support to this, Wilkinson (2003) reported that the growth rate of Juvenile tilapia increase, as dietary protein content is raised until a plateau is reached at around $30-34 \%$, further increase in dietary protein leads to decline the growth rate thereafter. In general, the results of the current study is in agreement 
with the previous findings on effects of dietary protein content on growth performance.

On the other hand, some studies demonstrated that tilapia need higher dietary protein levels for maximum growth. Jauncey (1982) showed that the growth of Juvenile O.mossambicus increased with dietary protein levels up to $38-40 \%$ and thereafter decreased with increasing protein level in diets. In addition, Santiago et al.,(1982) reported that the optimum dietary crude protein level for O.niloticus fry was between 35 and 40\%. AL-Hafedh (1999) and AlHafedh et al.,(1999) found out that the better growth of Nile tilapia was obtained at high dietary protein levels (40-45\%) rather than $25-35 \%$. The optimum dietary protein level for growth of tilapia fingerlings (20.3 g) and adults (40.6 g) was determined by Ahmad et al.(2004) to be 35\% protein diets.

The decline of growth rate in fish as dietary protein levels increases can be interpreted that at higher protein levels, a higher proportion of the energy available in the diet is supplied by protein instead of carbohydrates or lipid (Kim et al., 1991; Fah and Leng, 1986). Moreover, Jauncey (1982) postulated that the slight decrease in specific growth rate at protein levels above the optimum for juvenile tilapia, Sarotherodon mossambicus may be due to less dietary energy available for growth due to the energy needed to deaminate and excrete excess absorbed amino acids.

The considerable variations in the results recorded previously for optimum dietary protein requirements for maximum growth might be due to variations in fish size and age, stocking density, protein quality, hygiene and environmental conditions or other unknown factors, which mask the standardization of the parameters (Ahmad et al., 2004).

FCR, in the present study, was significantly affected by protein levels (Table 3). The best FCR (2.05) was obtained from 30\% protein diets, while the poorest FCR (2.72) was obtained at 20\% protein diets. These FCR trends are in agreement with that obtained by Siddiqui et al.(1988); Omar (1994 b); Kheir (1997); Abdel-Hakim et al.(2001). On the other hand, Wee and Tuan (1988) stated that better FCR values were obtained with increasing dietary protein levels up to $42.5 \%$ and deteriorated slightly by diet containing $50 \%$ protein. FCRs found by AL-Hafedh (1999) that ranged from 1.6 to 2.5 for fry (0.51 g) and from 3.13 to 4.86 for fingerlings fish ( $45 \mathrm{~g}$ ) were higher than those obtained in the present study. After a feeding period of 90 days by $27 \% \mathrm{CP}$, Tawwab (2004) recorded FCR of four Nile tilapia strains as follow: 2.21, 1.80, 2.17 and 2.03 for Abbassa, Aswan, Manzalah and Maryut strains respectively. The best FCR (1.92) of tilapia fingerlings (20.3 g) was obtained by Ahmad et al.(2004) using 35\% protein diet.

PER, in the present study, is significantly affected by protein level and reflects that protein utilization decreased by increasing dietary protein levels. The maximum protein utilization was obtained at low protein level (20\% CP). The decrease of PER with increasing dietary protein level has also been reported 
by different authors for different tilapia species (Jauncey, 1982; Wee and Tuan, 1988; Shiau and Huang, 1989; De Silva et al., 1989; Kheir, 1997; Ahmad et al., 2004). This is mainly because more dietary protein is used as energy when high protein diets are fed to fish (Kim et al., 1991). In support, Shimeno et al.(1981) found that increasing dietary carbohydrate and lipid caused a reduction in the activities of amino acid degrading enzymes in the hepatopancreas and resulted in a low nitrogen excretion rate and a high protein efficiency ratio.

In the present study, PER ranged from 1.34 to 1.85. PER in study of Khattab et al.(2000) ranged from 1.25 to 1.98 for Nile tilapia collected from Abassa fishponds $(12 \mathrm{~g})$. PER of tilapia fingerlings (20.3 g) reared using diet containing 25, 35, 45\% CP were 1.92, 1.58 and 1.19 respectively (Ahmad et al.,2004). PER of four Nile tilapia strains were 1.79, 2.20,1.82 and 1.95 for Abassa, Aswan, Manzala and Maryut strain respectively (Tawwab,2004). Dabrowski (1979) reported different patterns of changes in PER in relation to dietary protein level and found that the relationship between dietary protein and PER differs from species to species.

Biochemical analysis of fish carcass (Table 4) reveals that protein, lipid and moisture content were influenced significantly by dietary protein level. There was a significant increase in muscle protein and a decrease in lipid content with increasing dietary protein. Fish fed, $20 \%$ protein diet had lower content of protein and higher content of lipid than fish fed $25 \%$ or $30 \%$ or $35 \%$ protein diet.

Table (4): Biochemical analysis (on dry weight basis) of Nile tilapia carcass fed different levels of dietary protein.

\begin{tabular}{|c|c|c|c|c|c|c|c|c|c|c|c|c|c|c|}
\hline \multirow{2}{*}{ Parameters } & \multicolumn{12}{|c|}{ Protein level } & \multicolumn{2}{|c|}{ Anova } \\
\hline & \multicolumn{3}{|c|}{$20 \%$} & \multicolumn{3}{|c|}{$25 \%$} & \multicolumn{3}{|c|}{$30 \%$} & \multicolumn{3}{|c|}{$35 \%$} & F value & Sig. \\
\hline Moisture & 73,63 & \pm & $0.25^{\mathrm{ac}}$ & 72,77 & \pm & $0.05^{\mathrm{b}}$ & 73,43 & \pm & $0.35^{\mathrm{a}}$ & 74,07 & \pm & $0.15^{\mathrm{c}}$ & 12,86 & 0,002 \\
\hline $\begin{array}{l}\text { Crude } \\
\text { protein }\end{array}$ & 54,83 & \pm & $0.65^{\mathrm{a}}$ & 56,13 & \pm & $0.60^{\mathrm{b}}$ & 57,23 & \pm & $0.45^{\mathrm{c}}$ & 58,63 & \pm & $0.65^{\mathrm{d}}$ & 23,14 & 0,0 \\
\hline Total lipid & 23,83 & \pm & $0.49^{\mathrm{a}}$ & 22,67 & \pm & $0.55^{\mathrm{a}}$ & 20,57 & \pm & $1.05^{\mathrm{b}}$ & 19,27 & \pm & $0.40^{\mathrm{b}}$ & 25,36 & 0,0 \\
\hline Ash & 21,27 & \pm & 0,51 & 21,13 & \pm & 0,36 & 22,31 & \pm & 0,45 & 22,10 & \pm & 0,90 & 1,83 & 0,22 \\
\hline
\end{tabular}

Values with different superscripts within each row are significantly different at $\mathrm{p}<0.05$

This relationship was also noted by Dabrowski (1979) on grass carp, Jauncey (1982) on Sarotherodon mossambicus, Fah and Leng (1986) on guppy, Poecilia reticulate, Shiau and Huang (1989) on hybrid tilapia (O.niloticus $x$ O.aureus), Wee and Tuan (1988); Kheir (1997); AL-Hafedh (1999); Ahmad (2004) on Nile tilapia. The increase in muscle protein and decrease in lipid content with increasing dietary protein levels may be attributed to the high carbohydrate and low protein content in the diet of low protein level (Table 1). The excess carbohydrate in the diet may be converted into body fat for storage 
(Fah and Leng, 1986). Ash content was unaffected by dietary protein level. This result is similar to that obtained by Khattab et al.(2000) and Ahmad et al.(2004) for Nile tilapia collected from Abbassa fish ponds.

The results of the present study indicate that a diet containing 30\% protein appears to be economical and suitable for fingerlings of tilapia.

The long-term demand for aquaculture products is rising coincided with an increasing public awareness of the importance of fish for and human health and fitness that are driving fish consumption upwards. Correspondingly, the prospects for RAS are good. A number of experts believe that the future trend in the aquaculture industry is toward intensive fish farming.

\section{Recommendation}

Form the present results, the following points can be recommended:

1-Recirculating water system are suitable for Nile tilapia culture in Egypt.

2-Nile tilapia are well suited for aquaculture since they grow rapidly and are fairly resistant to stress and diseases.

3-A diet containing 30\% crude protein is an economical and suitable for Nile tilapia fingerlings feeding.

4-A stocking density of $60 \mathrm{fish} / \mathrm{m}^{3}$ is appropriate density for Nile tilapia culture in concrete tanks.

5-Fish grown in RAS must be supplied with all the conditions necessary to remain healthy and grow. They need a continuous supply of clean water at a temperature and dissolved oxygen content that is optimum for growth.

\section{Acknowledgement}

The authors wish to acknowledge the authorities of graduate studies, cultural affairs and research, Mansoura University for the financial support of the project (Intensive fish culture in tanks using recirculating water system) within which this work was conducted. The authors would like to thank the authorities of Damietta Faculty of Science for their cooperation and assistance. We extend our gratitude to all members of Zoology department, Damietta Faculty of Science for their continuous help.

\section{REFERENCES}

A.O.A.C.(1990). Official Methods of Analyses. $15^{\text {th }}$ edition. In: K. Helrich(ed.). Association of Official Analytical Chemists, Inc., Arlington, VA, USA.

Abdel-ghany, A.E. (2000). Optimum dietary protein requirements for Oreochromis niloticus L. fry using formulated semi-purified diets. Pp. 101-108. In: K. Fitzsimmons and J.C.Filho (eds.).Tilapia Aquaculture in the $21^{\text {st }}$ Century. Proceedings from the $5^{\text {th }}$ International Symposium on Tilapia Aquacult. Vol.1. 3-7 Sept.2000, Rio de Janeiro, Brazil. 
Abdel-Hakim, N.F. and Moustafa, S.T.(2000). Performance of Nile tilapia (Oreochromis niloticus) raised in cages as affected with stocking density and dietary protein level. Egyptian Journal of Aquatic Biology and Fisheries, 4: 95.

Abdel-Hakim, N.F., Hussein, M.S.,Bakeer, M.N. and Soltan, M.A.(2001). Effect of protein level and stocking density on growth performance of Nile tilapia (Oreochromis niloticus) cultured in tanks. Egypt. J. Nutrition and Feed, 4: 763-780.

Abdel-Tawwab, M. (2004). Comparative growth performance and feed utilization of four local strains of Nile tilapia (Oreochromis niloticus) collected from different locations in Egypt. Sixth international symposium on tilapia in aquaculture, Manila, Philippine.

Ahmad, M.H. (2000). Improve productive performance in fish. Ph.D. Dissertation, Animal Prod. Department, Faculty of Agriculture, Zagazig University.

Ahmad, M.H.; Abdel-Tawwab, M. and Khattab, Y. (2004). Effect of dietary protein levels on growth performance and protein utilization in Nile tilapia (Oreochromis niloticus) with different initial body weight. Sixth international symposium on tilapia in aquaculture, Manila, Philippine.

Akbulut, B., Sahin, T., Aksungur, M. and Aksungur, N.(2003). Effect of initial size on growth rate of rainbow trout, Oncorhynchus mykiss reared in cages on the Turkish Black Sea coast. Turkish J. Fisheries Aqua. Sci., 7: 133-136.

Al-Hafedh, Y.S. (1999). Effects of dietary protein on growth and body composition of Nile tilapia, Oreochromis niloticus L. Aquaculture Research, 30(5):385-393.

Al-Hafedh, Y.S.; Siddiqui, A.Q. and Al-Saiady, Y. (1999). Effects of dietary protein levels on gonad maturation, size and age at first maturity, fecundity and growth of Nile tilapia. Aquacult. Inter., 7(5): 319-332.

APHA, American Public Health Association (1992).: standard Methods for the Examination of water and wastewater. Washington, $18^{\text {th }}$ Edition. Dc.

Balarin, J.D. and Halfer, R.D.(1982). The intensive culture of tilapia in tanks, raceways and cages. pp. 265-356. In: J.F. Muir and R. J. Roberts (eds.). Recent Advances in Aquaculture, Crom Helm, London. 
Brazil, B.L.(2006). Performance and operation of rotating biological contractor in a tilapia recirculating aquaculture system. Aquaculture Eng., 34/3: 261274.

Charles, P.M.; Sebastian, S.M; Raj, M.C. and Marian, M.P. (1984). Effect of feeding frequency on growth and food conversion of Cyprinus carpio fry. Aquaculture, 40: 293-300.

Chiu,Y.N.; Sumagaysay, N.S. and Sastrillo, M. S.(1987). Effect of feeding frequency and feeding rate on the growth and feed efficiency of milkfish (Chanos chanos). Asian Fish. Sci., 1:27-31.

Coyle, S.D., Mengel, G.J., Tidwell, J.H. and Webster, C.D.(2004). Evaluation of growth, feed utilization and economics of hybrid tilapia, Oreochromis niloticus, Oreochromis aureus, fed diets containing different protein sources in combination with distillers dried grains with solubles. Aquacult. Res., 35: 365-370.

Dabrowski, K.(1979). Feeding requirements of fish with particular attention to common carp, A review.Polish Arch. Hydrobiol.,26: 135-158.

De Silva, S.S., Gunasekera, R.M. and Atapattu, D.(1989). The dietary protein requirements of young tilapia and an evaluation of the least cost dietary protein levels. Aquacult., 80:271.

El-Sayed, A.M. and Teshima, S.I.(1992). Protein and energy requirements of Nile tilapia, Oreochromis niloticus, fry. Aquacult. 103:55-63.

El-Sayed, A.M.(2002). Effects of stocking density and feeding levels on growth and feed efficiency of Nile tilapia (Oreochromis niloticus L.) fry. Aquacult. Res., 33: 621-626.

Fah, S.K.and Leng, C.Y.(1986). Some studies on the protein requirement of the guppy, Poecilia reticulate (Peters). J. Aquacult. \& Aquatic Sci., 44:1-12.

Fotedar, R.(2004). Effect of dietary protein and lipid source on the growth, survival, condition indices, and body composition of marron, Cherax tenuimanus (Smith). Aquacult. 230: 439-455.

Helfrich, L.and Libey, G. (2006). Fish farming in recirculating aquaculture systems (RAS). Recirculate Aqua Sys.htm. 
Jauncey, K. (1982). The effects of varying dietary protein level on the growth, food conversion, protein utilization and body composition of Juvenile tilapia (Sarotherodon mossambicus). Aquacult. 27: 43-54.

Khattab, Y.A.E.; Ahmad, M.H.; Shalaby, A.M.E. and Abdel-Tawwab, M.(2000). Response of Nile tilapia (Oreochromis niloticus L.) from different locations to different dietary protein levels. Egypt. J. Aquat. Biol. \&Fish., 4(4): 295-311.

Kheir, M.T.(1997). Growth of Oreochromis niloticus (Linnaeus, 1758) raised on feeds with different protein levels. Egypt. J.Zool. 28: 65-76.

Kim, K., Kayes, T.B. and Amundson, C.H. (1991). Purified diet development and reevaluation of the dietary protein requirement of fingerling rainbow trout (Oncorhyncus mykiss). Aquacult. 96: 57-67.

Losordo, T.M.; Masser, M.P. and Rakocy, J.(1998). Recirculating Aquaculture Tank production systems, An overview of critical considerations. Southern regional Aquaculture Center (SRAC) publication, No.451.

Meske, C. (1985). Fish Aquaculture. Pergamon Press, Oxford.

Omar, E.A.(1994b). Supplementary feeding of tilapia (Oreochromis niloticus) cultured in earthern ponds. 1-Effect of dietary protein levels and sources. Alex. J. Agric. Res. 39(2):109-128.

Pompa, T. and Masser, M.(1999). Tilapia, Life history and biology. Southern regional Aquaculture Center (SRAC) publication, No. 283.

Riche, M. and Garling, D.(2003). Feeding tilapia in intensive recirculating systems. North Central Regional Aquaculture Center, Fact sheet series, p.114.

Sampath, K.(1984).: Preliminary report on the effect of feeding frequency in Channa striatus. Aquaculture, 40: 301-306.

Santiago, C.B., Banes-Aldaba,M. And Laron, M.A.(1982). Dietary crude protein requirement of Tilapia nilotica fry. Kalikasan philipp. J. Biol., 11: 255265.

Sayed, A.F.M. (2006). Tilapia culture. CABI publishing, 320 pp. 
Shiau, S.Y.and Huang, S.L.(1989). Optimal dietary protein level for hybrid tilapia (Oreochromis niloticus * O. aureus) reared in seawater. Aquacult. 81: 119-127.

Shimeno, S., Takeda, M., Takayama, S. And Sasaki, H. (1981). Response of nitrogen excretion to change of dietary composition in carp. Bull. Japan.Soc. Sci.Fish., 47:191-195.

Siddiqui, A.Q., Howlader, M.S. and Adam, A.A. (1988). Effects of dietary protein levels on growth, feed conversion and protein utilization in fry and young Nile tilapia, Oreochromis niloticus. Aquacult., 70: 63-73.

Siddiqui, A.Q., Howlader, M.S. and Adam, A.A.(1989). Culture of Nile tilapia, Oreochromis niloticus (L.) at three stocking densities in outdoor concrete tanks using drainage water. Aquacult. Fish. Manag., 20 :49-57.

Snedecor, G.W. and Cochran, W.G.(1989). Statistical Methods. $8^{\text {th }}$ edition. Iowa state University Press.Iowa,USA.

Wang, K., Takeuchi, T. and Watanabe, T. (1985). Optimum protein and digestible energy levels in diets for Tilapia nilotica. Bull. Japan. Soc. Sci. Fish. pp. 51:141

Wee, K.L., Tuan, N.A.(1988). Effects of dietary protein level on growth and reproduction in Nile tilapia (Oreochromis niloticus). ICLARM Conference Proceedings, pp.15:623

Wilkinson, S. (2003). Aquaculture fundamentals, getting the most out of your feed, Part II: The role of macronutrients. Aquacult. Asia, 2: 6-9. 